\title{
New data on endohelminth communities of barbel Barbus barbus from the Bulgarian part of the River Danube
}

\author{
M. CHUNCHUKOVA, D. KIRIN \\ Department of Ecology and Environmental Protection, Agricultural University-Plovdiv, Mendeleev 12, 4000, Plovdiv, Bulgaria, \\ E-mail: m.chunchukova@abv.bg, dianaatanasovakirin@gmail.com
}

\section{Article info}

Received December 11, 2017 Accepted May 15, 2018

\begin{abstract}
Summary
Species diversity and composition of the parasite communities of barbel (Barbus barbus) at the infracommunity and component community levels were studied in the Lower Danube River, Bulgaria. During the two-year investigations, five parasite species have been found in 92 host fish: Bathybothrium rectangulum (Cestoda), Acanthocephalus anguillae and Pomphorhynchus laevis (Acanthocephala) and larval stages of Contracaecum sp. and Raphidascaris acus (Nematoda). Bathybothrium rectangulum and $R$. acus found in barbel represented new host records in Bulgaria. Parasite communities of barbel were species-poor and highly unbalanced. Pomphorhynchus laevis represented the dominant (core) species (prevalence $98.9 \%$ ), the second most frequent component parasite was Contracaecum sp. $(P=14.1 \%)$ and remaining three species occurred only accidentally in barbels. Differences in species richness, prevalence, intensity of infection and ecological indices between individual seasons (spring, summer, autumn) were statistically significant, but considerably affected by unequal species structure of communities with highly prevailing $P$. laevis. Low parasite species diversity of barbel and low values of most ecological indices, when compared with previous studies in this area (or other Bulgarian parts of the River Danube) might indicate that environmental conditions are impaired and thus, not favourable for the development of barbel parasites (primarily to their intermediate host survival) in the Lower Danube River of Bulgaria.

Keywords: Barbus barbus; helminths; parasite community structure; seasonality; Danube River; Bulgaria
\end{abstract}

\section{Introduction}

The River Danube is a longest river of the Central and Eastern Europe, which flows $2,860 \mathrm{~km}$ through ten countries or touches their borders. Its stream use to be divided into three broad sections with the delta representing a separate and unique system. The Upper Basin extends from the source in Germany, to the Devín Gate (Austria/Slovakia border), the Middle Section to Iron Gate dams (the Serbia/Romania border), and the Lower Section to the entrance of the Delta, with the whole section of the Bulgarian river bank (for review see Tubic et al., 2013). The barbel, Barbus barbus (Linnaeus, 1758) is indigenous to the ichthyofauna of the Danube Basin. As the potamodromous and benthopelagic species, it feeds chiefly on benthic invertebrates such as small crustaceans, insect larvae, molluscs, mayflies and midge larvae, but also small fish and occasionally algae (Froese \& Pauly, 2018). Parasite fauna of this fish reflects these food habits and local ecological conditions. The fish community in the shoreline zone of the Danube River 
in Bulgaria was investigated by Polačik et al. (2008). In this study, they identified 44 fish species, barbel, represented rarely occurring and low abundant fish species.

Fish and parasite communities from the lower section of the Danube River, including the Bulgarian part of the river, were often studied (Margaritov, 1959, 1966; Kulalovskaya \& Koval, 1973; Kakacheva-Avramova, 1977, 1983; Kakacheva et al., 1978; Nedeva et al., 2003; Polačik et al., 2008,; Atanasov, 2012; Kirin et al., 2013, 2014 etc.), but only Nachev \& Sures (2009) and Nachev (2010) examined specifically barbel.

The aim of this paper was to find the diversity of endoparasites of barbel and evaluate the structure of their communities in the Bulgarian part of the Lower Danube River.

\section{Materials and Methods}

During spring, summer and autumn of 2015 and 2016, a total of 92 specimens of barbel were collected from the Lower Danube

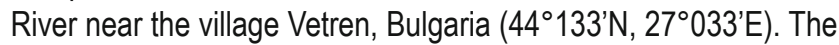
village is situated on the riverside, in the north-eastern part of the Danube Valley.

Barbels were caught using gill nets and by angling under a permit issues by the Ministry of Agriculture and Food of the Republic of Bulgaria. The scientific and common names of fishes are used according to the FishBase database (Froese \& Pauly, 2018).

The fish were weighed (a mean weight was $445.9 \pm 40.1 \mathrm{~g}$ and ranged between $220-788 \mathrm{~g}$ ) and measured (mean standard body length $36.1 \pm 1.0 \mathrm{~mm}$, range $290-450 \mathrm{~mm}$ ). Corresponding values for individual seasons are shown in the Table 1. The sample size can yield to reliable estimates the parasite abundance (Shvydka et al., 2018). The fish were immediately after their capture examined for gastrointestinal and tissue helmiths (an incomplete parasitological study) using standard techniques. Helminths were cleaned in a saline solution and fixed in $70 \%$ ethanol. Cestodes were stained with acetic carmine and mounted as permanent slides in a Canada balsam according to Georgiev et al. (1986) and Scholz \& Hanzelová (1998). Acanthocephalans and nematode larvae were examined as temporary slides in ethanol-glycerine and glycerine, respectively, and identified by use of keys by Petrochenko (1956), Bykhovskaya-Pavlovskaya (1985), Khalil et al. (1994) and Moravec (2013) and Lab Compound Microscope XS-213. In total, 6,408 adult or larval helminth specimens were collected (Table 2).

The helminth community structure was studied during three seasons at component community and infracommunity levels. Ecological terms were used according to Bush et al. (1997); a prevalence $(\mathrm{P}, \%)$, mean abundance (MA) and mean intensity of infection (MI). The component data were determined by the total number of species, Shannon diversity index ( $\left.H^{\prime}\right)$, Pielou's evenness index (E) and Berger-Parker dominance index (d) according to Magurran (2004). The dominance of the component helminths within communities was determined according to the prevalence criterion (P) proposed by Kennedy (1993) as accidental $(P<10)$, compo- nent $(10<P<20)$ and core $(P>20)$ species. The infracommunity data were calculated using the mean number of species, mean number of individual helminth specimens, Brillouin diversity index (HB), (Magurran, 2004; Kennedy, 1993, 1997). The quantitative similarity between parasite communities during three seasons was determined by the Sorensen index (Percentage similarity index, Ics), (Krebs, 1999).

The significance of seasonal changes in the prevalence and $\mathrm{Ml}$ was evaluated by the Chi-square $\left(X^{2}\right)$ and Two-sample t-test, respectively. A one-way ANOVA was used to compare the mean number of helminth species and the Brillouin diversity index within infracommunities, same as mean number of $P$. laevis with mean number of specimens of all other species. All statistical tests were performed using statistical software programs Quantitative Parasitology, version 3, Rozsa et al. 2000; STATISTICA 6.0 program and Microsoft Excel/Windows ${ }^{\circledR}$ XP Home Edition.

\section{Ethical Approval and/or Informed Consent}

This research carried out on fish has been complied with all the relevant national regulations and institutional policies for the care and use of animals.

\section{Results}

Helminth community structure of barbel

All barbels examined (92/92; $P=100 \%$ ) were infected and following parasite species were identified: the tapeworm Bathybothrium rectangulum (Bloch, 1782), thorny-headed worms Acanthocephalus anguillae (Müller, 1780) and Pomphorhynchus laevis (Zoega in Müller, 1776), and nematode larvae of Contracaecum sp. and Raphidascaris acus (Bloch, 1779). All but one are generalists, $B$. rectangulum is specific parasite to Barbus spp. (Protasova, 1977; Moravec et al., 1997). Adult stages of the cestode $B$. rectangulum and acanthocephalans $A$. anguillae and $P$. laevis (all autogenic) occurred in a host intestine. Allogenic nematode larvae were found either encapsulated in various internal organs and an intestine serosa, or free in abdominal cavity of infected fish.

\section{Infracommunities of barbel helminth endoparasites}

Species richness in helminth infracommunity of barbel ranged from one to three parasite species. A total of 74 fish individuals were infected with a single helminth species $(80.43 \%) ; 16$ barbels harboured two helminths (17.40\%); namely, 11 barbels were parasitized by $P$. laevis and Contracaecum larvae, two barbels by $P$. laevis and $B$. rectangulum, and three of them by $P$. laevis and $R$. acus larvae. Only two fish $(2.17 \%)$ were infected with three parasite species ( $P$. laevis, Contracaecum sp. and $B$. rectangulum). A maximum of 354 helminth specimens per fish host was detected. The average species richness (mean number of species in fish specimen) in infracommunities of barbel was $1.22 \pm 0.46$, the average abundance (mean number of helminth specimens in 
Table 1. Basic characteristics of Barbus barbus examined from the River Danube within individual seasons.

\begin{tabular}{lccc}
\hline Season & Number of fish & $\begin{array}{c}\text { Mean body length and } \\
\text { range }(\mathrm{mm})\end{array}$ & $\begin{array}{c}\text { Mean body weight } \\
\text { and range }(\mathrm{g})\end{array}$ \\
\hline Spring & 33 & $350.5(290-450)$ & $415.2(220-788)$ \\
Summer & 28 & $361.0(290-445)$ & $431.3(285-635)$ \\
Autumn & 31 & $371.0(310-420)$ & $491.3(395-745)$ \\
\hline
\end{tabular}

fish) was 69.6, Brillouin diversity index $\mathrm{HB}=0.075 \pm 0.079$ (range $0.008-0.166$ ). A comparison of the mean $\mathrm{HB}$ and the mean number of helminth species showed significant seasonal differences (Two-sample t-test, $p=0.00$ ). The mean number of specimens of $P$. laevis was significantly higher than the number of specimens of all other species in each season (One-way ANOVA, $p=0.03$ ).

\section{Component community of helminth endoparasites of barbel}

The vast majority $(6,340$ specimens) of the parasite component community of $B$. barbus composed two acanthocephalan species, followed by nematodes (49) and cestodes (19), with $P$. laevis as the most prevalent, core species ( $P=98.9 \%)$. Contracaecum sp. was proved as the second most frequent species ( $P=14.1 \%)$, while $B$. rectangulum $(P=4.4 \%), R$. acus $(P=3.3 \%)$, and $A$. anguillae $(P=1.1 \%)$ represented accidental species of the component community (Table 2).

The maxima of the mean intensity and mean abundance were detected in $P$. laevis in all seasons and thus, it represents the dominant species of the component community (Table 3). Significant differences were found between the number of $P$. laevis and the summary number of all other parasites in each season (Two-sample t-test, $p_{\text {spring }}=0.002, p_{\text {summer }}=0.03, p_{\text {autumn }}=0.002$ ). The prevalence of $P$. laevis and other parasite species also differed significantly (One-way ANOVA, $p_{P \text {. laevis/B. rectangulum }}=0.001, p_{P \text {. laevis/ } / \text {. anguillae }}=$ $\left.0.002, p_{P . \text { laevis/Contracaecum sp. }}=0.006, p_{P . \text { laevis } / \text {. acus }}=0.002\right)$. The same results were found for mean intensity of infection (One-way ANO$V A, p_{P . \text { laevis } / \text {. rectangulum }}=0.03, p_{P . \text { laevis } / \text {. anguillae }}=0.02, p_{P \text {. laevis } / \text { Contracaecum }}$ sp. $=0.01, p_{P . \text { laevis/R. acus }}=0.02$ ).

Contracaecum larvae showed much lower infection values throughout seasons with the highest prevalence and intensity of infection in summer (Table 3). Remaining parasites occurred solely in summer and autumn (B. rectangulum), only in summer
(A. anguillae) or only in autumn ( $R$. acus), always with a low infection (Table 3).

The highest component species diversity was found in summer and autumn, when four parasite species regularly occurred in barbels (Table 3). In spring, only two parasite species were detected; all barbels were infected with $P$. laevis and the only fish harboured two Contracaecum larvae. Above two species also occurred in $B$. barbus in all investigated seasons. The only fish specimen free of $P$. laevis occurred in summer, but it was infected with $A$. anguillae. The differences between the seasonal patterns of the $P$. laevis prevalence were not significant, similarly as between the intensity of infection, which culminated in spring $(\mathrm{Ml}=78.9)$. In Contracaecum sp. nematodes, significant seasonal differences were observed in both, the prevalence $\left(x^{2}, p=0.04\right)$ and mean intensity of infection between spring and summer (Two-sample t-test, $p=$ 0.00 ), spring and autumn (Two-sample t-test, $p=0.00$ ) and summer and autumn (Two-sample t-test, $p=0.01$ ). The mean intensity of infection of $B$. rectangulum was significantly higher in summer than in autumn (Two-sample t-test, $p=0.07$ ).

Taking into account all parasites except for $P$. laevis, significant differences were found between their mean intensity of infection and mean number of parasite specimens in summer and autumn (Two-sample t-test, $p=0.02$ and $p=0.008$, respectively).

Shannon diversity index and Pielou's evenness index were relatively low, with the lowest values in the spring period and the highest in summer (Table 4). On the contrary, Berger-Parker dominance index was the highest in spring (0.999) and lowest in summer (0.972). The Percentage similarity index (Ics) showed the highest similarity of helminth component communities of barbel between the spring and autumn periods (Ics $=0.989$ ), followed by that between summer and autumn (Ics $=0.981)$ and summer and spring (Ics $=0.973)$, but the differences were not significant.

Table 2. The prevalence $(\mathrm{P})$ and intensity values of helminth parasites detected in 92 barbels Barbus barbus from the River Danube.

\begin{tabular}{lccccc}
\hline Helminth species & $\begin{array}{c}\text { Number of fish infected } \\
\text { by individual parasite }\end{array}$ & $\mathrm{P}(\%)$ & $\begin{array}{c}\text { Number } \\
\text { of specimens }\end{array}$ & $\begin{array}{c}\text { Mean abundance } \\
\pm \mathrm{SD}\end{array}$ & $\begin{array}{c}\text { Mean intensity } \\
\pm \mathrm{SD}(\mathrm{range})\end{array}$ \\
\hline Bathybothrium rectangulum & 4 & 4.4 & 19 & $0.2 \pm 1.1$ & $4.8 \pm 2.9(1-9)$ \\
Acanthocephalus anguillae & 1 & 1.1 & 5 & $0.05 \pm 0.5$ & $5.0(5)$ \\
Pomphorhynchus laevis & 91 & 98.9 & 6,335 & $68.8 \pm 67.1$ & $69.6 \pm 67.1(2-354)$ \\
Contracaecum sp. larvae & 13 & 14.1 & 43 & $0.5 \pm 1.6$ & $3.3 \pm 3.0(1-12)$ \\
Raphidascaris acus larvae & 3 & 3.3 & 6 & $0.06 \pm 0.4$ & $2.0 \pm 0.8(1-3)$ \\
\hline
\end{tabular}


Table 3. Species diversity of helminth parasites of Barbus barbus from the River Danube within three seasons ( $\mathrm{N}$ - number of examined fish, $\mathrm{P}$ - prevalence (\%), Ml - mean intensity).

\begin{tabular}{lcccccc}
\hline Helminth species & $\begin{array}{c}\text { Spring } \\
(\mathrm{N}=33)\end{array}$ & \multicolumn{2}{c}{$\begin{array}{c}\text { Summer } \\
(\mathrm{N}=28)\end{array}$} & \multicolumn{2}{c}{$\begin{array}{c}\text { Autumn } \\
(\mathrm{N}=31)\end{array}$} \\
\hline & $\mathrm{P}$ & $\mathrm{Ml}$ (range) & $\mathrm{P}$ & $\mathrm{Ml}$ (range) & $\mathrm{P}$ & $\mathrm{Ml}$ (range) \\
\hline Bathybothrium rectangulum & - & - & 3.6 & $9.0(9)$ & 9.7 & $3.3(1-5)$ \\
Acanthocephalus anguillae & - & - & 3.6 & $5.0(5)$ & - & - \\
Pomphorhynchus laevis & 100.0 & $78.9 \pm 67.8$ & 96.4 & $60.1 \pm 68.6$ & 100.0 & $68.0 \pm 63.5$ \\
& & $(2-341)$ & & $(2-354)$ & & $(2-237)$ \\
Contracaecum sp. larvae & 3.0 & $2.0(2)$ & 21.4 & $5.3(3-12)$ & 19.4 & $1.5(1-2)$ \\
Raphidascaris acus larvae & - & - & - & - & 9.7 & $2.0(1-3)$ \\
\hline
\end{tabular}

\section{Discussion}

Even though the parasitofauna of various fish species from the Lower Danube River, including its Bulgarian part, had been relatively often investigated (see the Introduction), data on helminths of barbel B. barbus were infrequently recorded. Summary data of the Table 5 show that helminth communities vary more or less in individual years. For instance, the cestode $B$. rectangulum (Bothriocephalidea) had so far been reported only from Barbus meridionalis and Barbus cyclolepis in Bulgaria (Kakacheva-Avramova, 1983). We have found this parasite in the $B$. barbus that represents the new host record in the Lower Danube River and even in Bulgaria.

Compared to $B$. rectangulum, acanthocephalans $A$. anguillae and $P$. laevis (both Echinorhynchida) have much broader fish host spectrum in the Danube River. Acanthocephalus anguillae is a euryxenous parasite having a wide host range, which includes at least 40 fish species (Moravec, 2001). In the Lower Danube River, this species was commonly referred in B. barbus by Margaritov (1959, 1966), Kakacheva-Avramova (1977), Kakacheva et al. (1978), Nachev \& Sures (2009), Djikanovic et al. (2010) and Atanasov (2012), but it also often occurs in the Upper and Middle Danube sections (Moravec 2001; Moravec et al., 1997; Djikanovic et al., 2012). The other common thorny-headed worm $P$. laevis has often been reported from various fish hosts including barbel, through the whole Danube River flow (e.g. Molnár, 1970; Moravec et al. 1997; Moravec, 2001; Schludermann et al., 2003; Ondračková et al., 2005; Djikanovic et al. 2010, 2012). In Bulgarian part of the Danube River, $P$. laevis was found in as many as 20 fish species including B. barbus (Nedeva et al., 2003). More recently, Nachev \& Sures (2009) and Nachev (2010) also showed P. laevis as very frequent species in this location.

Acanthocephalans of the genus Pomphorhynchus have been intensively studied during the past decades. In Europe, Pomphorhynchus species have shown a certain degree of variability in their morphological characteristics and behaviour, which caused difficulties with their correct identification. Nowadays, the comprehensive molecular study on the phylogeography of European populations of $P$. laevis and $P$. tereticollis (Rudolphi, 1809) has been done by Perrot-Minnot et al. (2018) and it appears that only $P$. laevis occurs through the main flow of the River Danube. The study additionally showed rare co-occurrence of these species in the same habitats, several small rivers and a lake from the Danube River Basin. In this respect, the recent findings of $P$. tereticollis in Abramis brama from the Bulgarian lake Srebarna, adjacent to the Danube River (Kirin et al., 2013; 2014) is of greatest interest and needs additional study (Špakulová, personal communication). The coexistence of $P$. laevis and $P$. tereticollis had also been documented both in fish and intermediate gammarid hosts in different localities of Europe (Perrot-Minnot, 2004; Westram et al., 2011; Perrot-Minnot et al., 2018).

Nematode larvae were rarely referred in fishes of the Lower Danube; except of the recently found Contracaeum and Raphidascaris representatives, only Eustrongylides sp. and Hysterothylacium sp.

Table 4. Comparison of seasonal diversity of helminth communities of Barbus barbus from the River Danube.

\begin{tabular}{lccc}
\hline \multicolumn{1}{c}{ Season } & Spring & Summer & Autumn \\
\hline Number of helminth species & 2 & 4 & 4 \\
Number of helminth specimens & 2606 & 1669 & 2133 \\
$H^{\prime}$ (Shannon, diversity index) & 0.006 & 0.149 & 0.076 \\
E (Pielou, evenness index) & 0.009 & 0.107 & 0.055 \\
d (Berger-Parker, dominance index) & 0.999 & 0.972 & 0.988 \\
Dominant species & P. laevis & P. laevis & P. laevis \\
\hline
\end{tabular}


Table 5. Overview of helminth species of Barbus barbus recorded in the lower section of the River Danube.

\begin{tabular}{|c|c|c|c|c|c|c|}
\hline Helminth species & $\begin{array}{c}\text { Margaritov } \\
(1959)\end{array}$ & $\begin{array}{c}\text { Margaritov } \\
(1966)\end{array}$ & $\begin{array}{c}\text { Kakacheva- } \\
\text { Avramova } \\
(1977)\end{array}$ & $\begin{array}{c}\text { Nachev } \\
\text { \& Sures } \\
(2009)\end{array}$ & $\begin{array}{c}\text { Atanasov } \\
(2012)\end{array}$ & This study \\
\hline \multicolumn{7}{|l|}{ Cestoda } \\
\hline Bathybothrium rectangulum & & & & & & $\bullet$ \\
\hline Caryophyllaeus laticeps & $\bullet$ & $\bullet$ & & & $\bullet$ & \\
\hline Caryophyllaeus fennica & & $\bullet$ & & & $\bullet$ & \\
\hline \multicolumn{7}{|l|}{ Monogenea } \\
\hline Dactylogyruscarpathicus & & & $\bullet$ & & & \\
\hline Dactylogyrusmalleus & $\bullet$ & & $\bullet$ & & & \\
\hline Dactylogyrussphyrna & & & $\bullet$ & & & \\
\hline Diplozoon sp. & & & $\bullet$ & & & \\
\hline \multicolumn{7}{|l|}{ Trematoda } \\
\hline Metagonimus yokogawai larv. & & & & $\bullet$ & $\bullet$ & \\
\hline Diplostomum spathaceum larv. & & & & $\bullet$ & $\bullet$ & \\
\hline Diplostomum pseudospathaceum larv. & & & & & $\bullet$ & \\
\hline Posthodiplostomum cuticola larv. & & & & $\bullet$ & & \\
\hline \multicolumn{7}{|l|}{ Nematoda } \\
\hline Rhabdochona hellichi & & & $\bullet$ & $\bullet$ & $\bullet$ & \\
\hline Rhabdochona denudata & & & & & $\bullet$ & \\
\hline Rhabdochona sulaki (=gnedini) & & $\bullet$ & & & & \\
\hline Rhaphidascaris acus larv. & & & & & & $\bullet$ \\
\hline Pseudocapillaria tomentosa & & & & $\bullet$ & & \\
\hline Eustrongylides sp. larv. & & & & $\bullet$ & & \\
\hline Contracaecum sp. larv. & & & & & & $\bullet$ \\
\hline Hysterothylacium sp. larv. & & & & $\bullet$ & & \\
\hline \multicolumn{7}{|l|}{ Acanthocephala } \\
\hline Pomphorhynchus laevis & $\bullet$ & $\bullet$ & $\bullet$ & $\bullet$ & $\bullet$ & $\bullet$ \\
\hline Acanthocephalus anguillae & & & & $\bullet$ & $\bullet$ & $\bullet$ \\
\hline Leptorhynchoides plagicephalus & & & & $\bullet$ & & \\
\hline
\end{tabular}

were found by Nachev \& Sures (2009) and Nachev (2010). In Europe, larvae of the ascaridoid genus Contracaecum sp. (Rhabditida) often occurred in internal organs of a wide spectrum of mainly cyprinid and perciform fishes. Up to ten Contracaecum species are available at the moment, but the systematics of their larval stages is difficult and little elaborated (Moravec, 2013). Therefore, supplementary molecular analyses of our Contracaecum samples would be beneficial to confirm species determination. We suppose, however, that it could be Contracaecum microcephalum (Rudolphi, 1809), because it was repeatedly reported from several other fish species in the River Danube in Bulgaria (Shukerova, 2006; Shukerova et al., 2010; Chunchukova et al., 2016).

Raphidascaris acus larvae (Rhabditida) occur in many fish species of different families of wide Holarctic distribution, most often in cyprinids (Moravec, 2013). In Bulgarian part of the Danube River and the lake Srebarna, larvae of $R$. acus were to date found in three cyprinids, Abramis brama, Alburnus alburnus, Squalius cephalus and Perca fluviatilis (Shukerova 2010; Shukerova et al., 2010; Chunchukova et al., 2017). In Upper and Middle Danube sections, $R$. acus was found frequently in various fishes including barbels (e.g. Moravec et al., 1997; Moravec, 2001; Ondračková et al., 2005). Regarding Bulgaria, the recent report of $R$. acus larvae in barbel represents the new geographic and host record.

Information about seasonal changes of the fish helminth community structure is of great value for any studies on fish parasites and ecological assessment of freshwater habitats. Considering the seasonal changes in the component community structure, it comprised four parasites in summer (B. rectangulum, A. anguillae, 
P. laevis and Contracaecum sp.) and in autumn (B. rectangulum, $P$. laevis, Contracaecum sp. and $R$. acus) and only two helminths ( $P$. laevis and Contracaecum sp.) in spring. Only Contracaecum larvae were found in all three seasons round, being accidental in spring $(3.0 \%)$, core in summer $(21.4 \%)$, and component species in autumn (19.4\%). Numerous, mainly cyprinid fish including barbel (genera Abramis, Alburnoides, Alburnus, Barbus, Gobio, Rutilus), represent intermediate or paratenic hosts of Contracaecum nematodes (Moravec et al., 1997).

In the present study, $P$. laevis was the most abundant (core) species during all studied seasons of two years. It dominated significantly all other helminths in the number of specimens, prevalence and mean intensity of infection. Seasonal differences between these indices were not significant, which partly coincide with a life cycle mode of $P$. laevis, which is not seasonally dependent, same as a composition of the food of barbel. Potential decline of infection rates of the parasite might be related to availability of gammarid intermediate host in preferred habitats. It should be remembered that this parasite, in high numbers, may significantly affect the health status of the host fish and can cause substantial loss and even destruction of its populations, including in aquaculture (Moravec et al., 1997; Gettová et al., 2016).

The stenoxenous $B$. rectangulum was classified as the parasite of barbel with an accidental incidence. Its mean intensity increased in summer, the maximum prevalence was quoted during autumn, but was completely absent in the study site in spring. In other Danube habitats, however, it occurred during the whole year including spring seasons (Scholz \& Moravec, 1996; Moravec et al., 1997). These authors described a seasonal cycle of this tapeworm and explained that worms with ripe eggs left the fish hosts from May to July. Reproduction cycle of Bathybothrium might be modified by specific local environmental conditions, which could the lack of the species recorded by us in spring. The host specificity of $B$. rectangulum discussed Kakacheva-Avramova (1983), who found this species also in Gobio gobio or S. cephalus, but the cestode had never reached sexual maturity in these fish hosts.

In the lower Danube, some helminth species seems to be rather rare. Only five specimens of the acanthocephalan $A$. anguillae were found in a single fish host screened in summer, and only six nematode larvae the $R$. acus were found in three barbels screened in autumn. The number of studies (for review see Moravec et al., 1997) showed clear seasonal dynamics in occurrence of this nematode with maximum in autumn, decrease in winter, second maximum in spring and minimum in summer. At the same time, significant variations were reported by the habitats, fish size and age and specific fish host diet.

Taking into account all parasites except of $P$. laevis, their mean intensity of infection and mean number of parasite specimens were significantly higher in summer comparing with autumn. The Brillouin diversity index (HB) was significantly higher in summer than in autumn, while the maximum values of Shannon diversity and the Pielou's evenness indices were documented higher in sum- mer but contrary to $\mathrm{HB}$, they were lowest in spring. These results indicate better biotic and environmental conditions for a majority of barbel parasites in summer seasons (Hudson et al., 2006). Evaluating the complex information including $P$. laevis data, most indices have changed significantly due to the unbalanced number of individual parasite species (significantly prevailing $P$. laevis) in the examined data set in all seasons. The Shannon diversity and the Pielou's evenness indices were low, while the Berger-Parker dominance and Sorensen similarity indices were relatively high (see Table 4). Berger-Parker dominance index was the highest in the spring period and lowest in summer, in accordance with the dominance of $P$. laevis in the data set.

Our study of endohelminth community of $B$. barbus from the Lower Danube (biotope Vetren) corresponds only partially with previous surveys by Margaritov $(1959,1966)$, Kakacheva-Avramova (1977), Nachev \& Sures (2009), and Atanasov (2012) (Table 5). The spectrum of barbel parasites differed depending on the study site, number of examined fish, and various ecological factors like fish feeding habits and water quality. The number of helminth species, reported by above papers, ranged between three (Margaritov, 1959) and 10 taxa (Nachev \& Sures, 2009). Caryophyllidean cestodes, acanthocephalans (mainly the dominating $P$. laevis) and nematodes (the obligate Rhabdochona spp.) were most common, while trematodes (e.g. Diplostomum sp. larvae) often absent and monogeneans were most probably rarely checked. Significant differences in the parasite diversity of barbel have been found between our study, other Danube River sites or areas geographically close to the Danube (Moravec et al., 1997; Schludermann et al., 2003; Nachev, 2010). Relatively low parasite species diversity of barbel recorded during two years, and low values of most indices might indicate some negative environmental conditions in the studied area, which should be subsequently reviewed.

\section{Conflict of Interest}

Authors state no conflict of interest.

\section{Acknowledgement}

We are grateful to M. Špakulová and V. Hanzelová for their valuable suggestions.

\section{References}

AtanAsov, G. (2012): Fauna, morfologiya i biologiya na endokhelminti po ribi ot bǔlgarskiya uchastŭk na reka Dunav [Fauna, morphology and biology on the endohelminths of fish from Bulgarian part of the Danube River]. PhD thesis, Bulgaria, Sofia: Bulgarian Academy of Science (In Bulgarian)

Bush, A., Lafferty, K., Lotz, J., Shostak, A. (1997): Parasitology meets ecology on its own terms. J. Parasitol., 83: 575 - 583. DOI: $10.2307 / 3284227$ 
Bykhovskaya-Pavlovskaya, I. (1985): Parazity ryb: rukovodstvo po izucheniyu [Parasites of fish: Manual on study], Nauka, Leningrad, 121 pp. (In Russian)

Chunchukova, M., Shukerova, S., KIRIN, D. (2016): Research of the impact of river Danube on Biosphere Reserve "Srebarna" by model ecosystem Abramis brama - macroinvertebrates - sediments. Agricultural Sciences / Agrarni Nauki, Agricultural University Plovdiv, 8(19): 151 - 158. DOl: 10.22620lagrisci.2016.19.023

Chunchukova, M., Kirin, D., Kuzmanova, D., Shukerova, S. (2017): Accumulation of lead in Abramis brama and its parasite Pomphorhynchus tereticollis from Danube river (Vetren area). Scientific Papers. Series D. Animal Science., 60: 327 - 332

DJIKANOVIC, V., GACIC, Z., CAKIC, P. (2010): Endohelminth fauna of barbel Barbus barbus (L. 1758) in the Serbian section of the Danube River, with dominance of acanthocephalan Pomphorhynchus laeavis. Bull. Eur. Ass. Fish Pathol., 300: 229 - 236

Duikanovic, V., Paunovic, M., Nikolic, V., Simonovic, P., Cakic, P. (2012): Parasitofauna of freshwater fishes in the Serbian open waters: a checklist of parasites of freshwater fishes in Serbian open waters. Rev. Fish Biol. Fisheries, 22(1): 297 - 324. DOI: 10.1007/ s11160-011-9226-6

Froese, R., Pauly, D. (2018) Editors. FishBase. World Wide Web electronic publication.

www.fishbase.org, version (10/2017).

Georgiev, B., Biserkov, V., Genov, T. (1986): In totostaining method for cestodes with iron acetocarmine. Helminthologia, 23: 279 - 281 Gettová, L., GILles, A., Šımková A. (2016): Metazoan parasite communities: support for the biological invasion of Barbus barbus and its hybridization with the endemic Barbus meridionalis. Parasit. Vectors, 9: 588. DOI: doi.org/10.1186/s13071-016-1867-9

Hudson, P. J., Dobson, A. P., Lafferty, K. D. (2006): Parasites and ecological systems: is a healthy system one with many parasites? Trends Ecol. Evol., 21: 381 - 385. DOI: doi.org/10.1016/j. tree.2006.04.007

KaKaCheVA-Avramova, D. (1977): Izsledvane khelmintite na ribi ot Bŭlgarskiya uchastŭk na r. Dunav [Studies on helminths of fishes in the Bulgarian section of the Danube River]. Khelminthologia, 3: $20-45$ (In Bulgarian)

KaKaCheVA-AvRamova, D. (1983): Khelminti na sladkovodnite ribi v Bŭlgariya [Helminths of freshwater fishes in Bulgaria]. Bulgarian Academy of Science, Sofia, 261 pp. (In Bulgarian)

Kakacheva-Avramova, D., Margaritov, N., Grupcheva, G. (1978): Paraziti u ribi ot Bŭlgarskiya uchastŭk na r. Dunav [Fish parasites of Bulgarian part of the Danube River]. In: Limnology of Bulgarian part of the Danube River, Bulgarian Academy of Science, pp. 250 - 268 (In Bulgarian)

KENNEDY, C. (1993): The dynamics of intestinal helminth communities in eels Anguilla anguilla in a small stream: long-term changes in richness and structure. Parasitology, 107: 71 - 78. DOI: 10.1017/S0031182000079427

Kennedy, C. (1997): Freshwater fish parasites and environmental quality, an overview and caution. Parassitologia, 39: 249 - 254
KhaliL, L.F., Jones, A., Bray, R.A. (1994): Keys to the cestode parasites of vertebrates. Wallingford, Oxon, CAB International, $751 \mathrm{pp}$. Kirin, D., Hanzelová, V., Shukerova, S., Hristov, S., Turčeková, L., ŠPAKULOVÁ, M. (2013): Helminth communities of fishes from the River Danube and Lake Srebarna, Bulgaria. Scientific Papers. Series D. Animal Science, 56: $333-340$

Kirin, D., Hanzelová, V., Shukerova, S., Kuzmanova, D. (2014): Biodiversity, bioindication and helminth communities of Abramis brama (Linnaeus, 1758) from the Danube River and Srebarna Lake, Bulgaria. Turkish Journal of Agricultural and Natural Sciences, Special Issue 1: $727-733$

KreBS, C.J. (1999): Ecological Methodology, $2^{\text {nd }}$ edition. Menlo Park, California: Benjamin/Cummings Publishing, 620 pp.

Kulakovskaya, O. P., Koval, V. P. (1973): Parazitofauna ryb basseyna Dunaya [Parasite fauna of fishes of the Danube basin]. Naukova Dumka, Kiev, 211 pp. (In Russian)

MagurRan, A.E. (2004): Measuring Biological Diversity. Oxford: Blackwell Publishing, 264 pp.

Margaritov, N. (1959): Paraziti po nyakoi nashi sladkovodni ribi [Parasites of some freshwater fishes]. Publishing House NIRRP, Varna, 21 pp. (In Bulgarian)

MARgARITOV, N. (1966): Khelminti na khranosmilatelnata sistema i telesnata praznina na ribite ot Bŭlgarskiya uchastǔk na r. Dunav [Helminths of the digestive tract and the abdominal cavity of fishes of the Bulgarian section of Danube River]. Bulletin de l'Institut de Zoologie et Musée de l'Academie des Sciences de Bulgarie, 20: 157 - 173. (In Bulgarian)

MolnÁR, K. (1970) Beiträge zur Kenntnis der Fischparasitenfauna Ungarns VI. Cestoda, Nematoda, Acanthocephala, Hirudinea [Contributions to the knowledge of the fish parasite fauna of Hungary VI. Cestoda, Nematoda, Acanthocephala, Hirudinea]. Parasit. Hung., 3: 51 - 76. (In German) http://publication. nhmus.hu/pdf/parhung/Parasit_Hung_1970_Vol_3_51.pdf

Moravec, F. (2001): Checklist of the Metazoan Parasites of Fishes of the Czech Republic and Slovak Republic. Academia, Praha, $168 \mathrm{pp}$.

Moravec, F. (2013): Parasitic nematodes of freshwater Fishes of Europe. Revised second edition, Academia, Praha, 601 pp.

Moravec, F., Konečný, R., Baska, F., Rydlo, M., Scholz, T., MolNÁR, K., SCHIEMER, F. (1997): Endohelminth fauna of barbel, Barbus barbus (L.), under ecological conditions of the Danube basin in Central Europe. Academia, Praha, Studie AV ČR 3/1997, 96pp.

NACHEV, M. (2010): Bioindication capacity of fish parasites for the assessment of water quality in the Danube River. PhD thesis, Germany, Essen: University of Duisburg-Essen, https://duepublico. uni-duisburg-essen.de/servlets/DerivateServlet/Derivate-24927/ Dissertation_Nachev.pdf

NACHEV, M., SuRES, B. (2009): The endohelminth fauna of barbel (Barbus barbus) correlates with water quality of the Danube River in Bulgaria. Parasitology, 136: 545 - 552. DOI: 10.1017/ S003118200900571X

Nedeva, I., Atanassov, G., Karaivanova, E., Cakic, P., Lenghardt, M. 
(2003): Pomphorhynchus laevis (Müller, 1776) from the River Danube. Experimental Pathology and Parasitology 6: $14-16$

OndračKová, M., DÁvidová, M., PeČínKová, M., BlažEK, R., Gelnar, M., Valová, Z., Černý, J., JuRAJdA, P. (2005): Metazoan parasites of Neogobius fishes in the Slovak section of the River Danube. J. Appl. Ichthyol. 21: 345 - 349. DOI:10.1111/j.1439-0426.2005.00682.x

Perrot-Minnot, M-J, Špakulová, M., Wattier, R., Kotlík, P., Düşen, S., AydoĞdu A., Tougard, C. (2018): Contrasting phylogeography of two Western Palaearctic fish parasites despite similar life cycles. J. Biogeograph. 45: 101 - 115. DOI: 10.1111/jbi.13118

Perrot-Minnot, M.-J. (2004): Larval morphology, genetic divergence, and contrasting levels of host manipulation between forms of Pomphorhynchus laevis (Acanthocephala). Int. J. Parasitol., 34: 45 - 54. DOI: doi.org/10.1016/j.ijpara.2003.10.005

Petrochenko, V.I. (1956): Akantotsefaly (skrebni) domashnikh $i$ dikikh zhivotnykh [Acanthocephala of Domestic and Wild Animals]. Izdatelstvo Akademii Nauk SSSR, Moskva, Vol. I, 435 pp. (In Russian)

PolačIK, M., Trichkova, T., JanÁč, M., Vassilev, M., JuRajda, P. (2008). The ichthyofauna of the shoreline zone in the longitudinal profile of the Danube River, Bulgaria. Acta Zool. Bulg., 60: 77 - 88 Protasova, E.N. (1977): Osnovyy sestodologii. VIII. Botriotsefalyaty - lentochnyye gel'minty ryb [Bases on the Cestodology. VIII. Bothriocephalata - Tapeworms of fish]. Nauka, Moskva, 298 pp. (In Russian)

Rozsa, L., Reiczigel, J., Majoros, G. (2000): Quantifying parasites in samples of hosts. J. Parasitol., 86: 228 - 232. DOI: 10.1645/0022-3395(2000)086[0228:QPISOH]2.0.CO;2

Scholz, T., MoRAVEC F. (1996): Seasonal occurrence and maturation of Bathybothrium rectangulum (Cestoda: Amphicotylidae) in barbel Barbus barbus (Pisces) of the Jihlava River, Czech Republic. Parasite, 31: 39 - 44. DOI: 10.1051/parasite/1996031039 Scholz, T., Hanzelová, V. (1998): Tapeworms of the genus Proteo- cephalus Weinland, 1858 (Cestoda: Proteocephalidae), parasites of fishes in Europe. Academia, Praha. Studie AV ČR, 119 pp.

Schludermann, C., Konecny, R., Laimgruber, S., LeWIS, J.W., Schiemer, F., Chovanec, A., Sures, B. (2003): Fish macroparasites as indicators of heavy metal pollution in river sites in Austria. Parasitology, 126: s61 - s69. DOI: 10.1017/S0031182003003743

ShUKEROVA, S. (2006): Helminth fauna of the common carp, Cyprinus carpio (Linnaeus, 1758), from the Srebarna Biosphere Reserve, Bulgaria. Scientific Articles. Ecology 2006, Part 2: 217 - 223 SHUKEROVA, S. (2010): Хелминти и хелминтни съобщества на рибите om бисфререн резерват „Сребърна” [Helminths and helminth communities of freshwater fish from Biosphere Reserve Srebarna]. PhD thesis, Bulgaria, Plovdiv: Agricultural University (In Bulgarian)

Shukerova, S., KiRIn, D., Hanzelova, V. (2010): Endohelminth communities of the perch, Perca fluviatilis (Perciformes, Percidae) from Srebarna Biosphere Reserve, Bulgaria. Helminthologia, 47: 99 - 104. DOI: 10.2478/s11687-010-0016-9

Shvydka, S., Sarabeev, V., Estruch, V. D., Cadarso-Suárez, C. (2018): Optimum sample size to estimate mean parasite abundance in fish parasite surveys. Helminthologia, 55: 52 - 59. DOI: https://doi.org/10.1515/helm-2017-0054

Tubic, B.T., Simic, V.M., Zoric, K.S., Gačic, Z.M., Atanackovic, A.D., Csányı, B.J., Paunovic, M.M. (2013): Stream section types of the Danube River in Serbia according to the distribution of macroinvertebrates. Biologia, 68: 294 - 302. Section Zoology. DOI: 10.2478/ s11756-013-0152-z.

Westram, A.M., Baumgartner, C., Kellera, I., Jokela, J. (2011): Are cryptic host species also cryptic to parasites? Host specificity and geographical distribution of acanthocephalan parasites infecting freshwater Gammarus. Infect. Genet. Evol. 11: 1083 - 1090. DOI: 10.1016/j.meegid.2011.03.024 